\title{
GUSTAVO BARROSO E A FABRICAÇÃO DA HISTÓRIA: costuras entre politica e literatura no discurso barrosiano 1917-1920
}

\author{
Elynaldo Gonçalves Dantas*
}

RESUMO: A partir da operação historiográfica proposta por Michel de Certeau e da concepção benjaminiana acerca da história esta reflexão busca analisar como Gustavo Barroso faz caminhar pari passu sua atuação política enquanto deputado federal e seu texto Os Dragões do Rei, em torno do tema do projeto de lei de 1917 de sua autoria apelidado de os Dragões da Independência no sentido de religar o passado ao presente e assim moldar um rosto nacional.

PALAVRAS-CHAVE: Gustavo Barroso; História; Literatura.

\section{Gustavo Barroso and the fabrication of history: seams between politics and literature in barrosiano discourse 1917-1920}

\begin{abstract}
From the historiographical operation proposed by Michel de Certeau and the Benjaminian conception about history this reflection seeks to analyze how Gustavo Barroso makes his political action pari passu as a federal deputy and his text Os Dragões do Rei, around the theme of the bill of 1917 of its authorship denominated Os Dragões da Independência in the sense to reconnect the past to the presente and thus to mold a national face.
\end{abstract}

KEYWORDS: Gustavo Barroso; History; Literature.

\section{Gustavo Barroso y la fabricación de la historia: costuras entre política y literatura en el discurso barrosiano 1917-1920}

RESUMEN: Desde la operación historiográfica propuesta por Michel de Certeau y de la concepción benjaminiana de la historia, esta reflexión busca analizar cómo Gustavo Barroso hace su acción política como pari passu como diputado federal y su texto Os Dragões do Rei, en torno al tema de la ley de 1917 de su autoría denominada Os Dragões da Independência en el sentido de reconectar el pasado con el presente y así moldear una cara nacional.

PALABRAS CLAVE: Gustavo Barroso; Historia; Literatura.

\footnotetext{
* Mestre e Bacharel em História pela Universidade Federal do Rio Grande do Norte. Atualmente, doutorando em História Social pela Universidade Federal do Ceará. Atua e tem interesse nas seguintes áreas: espaço, política, História e Literatura, identidade, Estado, poder e representações culturais. Contato: Universidade Federal do Ceará, Av. da Universidade, 2853, Benfica, CEP: 60020-181, Fortaleza-CE, Brasil. E-mail: elynaldohis@gmail.com.
} 


\section{Introdução}

Não há documento da cultura que não seja ao mesmo tempo um documento da barbárie. E assim como os próprios bens culturais não estão livres, também não o está o processo de transmissão com que eles passam de uns a outros. Por isso, o materialista histórico se afasta o máximo possível da tradição. Ele considera como tarefa sua pentear a história a contrapelo.

Walter Benjamin

Gustavo Adolfo Luíz Guilherme Dodt da Cunha Barroso nasceu na cidade de Fortaleza, Ceará, no dia 29 de dezembro de 1888, filho de Antônio Filinto Barroso, pertencente a uma tradicional família rural cearense em declínio econômico, e de Ana Dodt Barroso, descendente de imigrante alemão. Seus primeiros estudos se deram no colégio laico Partenón Cearense, em 1898. Seu curso secundário foi no Liceu do Ceará, em 1899, ingressando na Faculdade de Direito do Ceará em 1907.

Nesse período, em que a oligarquia Accioly encabeçava o quadro político cearense, Barroso começa a desenvolver atividades letradas ao escrever para órgãos da imprensa local. Aos 19 anos de idade, em 1907, sua postura nos jornais começa a se destacar pelo forte oposicionismo ò oligarquia de Nogueira Accioly ${ }^{1}$. Esse ano também marca a estreia de Barroso na imprensa nacional e sua participação em grêmios literários. No ano de 1910, Barroso passa a residir na capital do país, Rio de Janeiro, onde conclui seu curso de Direito em 1912, em concomitância à sua atividade de escritor e redator de jornais e revistas como A Careta, Tico-Tico, Fon-Fon e Jornal do Comércio, mesmo ano em que publica seu primeiro e renomado livro, Terra de Sol.

No ano de 1914, Gustavo Barroso retorna ao estado do Ceará para assumir o cargo de secretário do Interior e da Justiça do governo do seu primo Liberato Barroso. Sendo eleito Deputado Federal pelo Ceará na legenda do Partido Republicano Conservador, seu mandato (1915-1918) é marcado por discursos e propostas contra a seca, pelo seu projeto de lei contra a entrada no Brasil de pessoas consideradas indesejadas, por seu ingresso na comissão de Marinha e Guerra e pelo projeto dos "Dragões da Independência".

E é justamente sobre os desdobramentos em torno do projeto de lei 71 de 1917, apelidado de Dragões da Independência, que versa esse artigo. Desdobramentos esses que extrapolaram as dinâmicas do âmbito político e se fizeram sentir na escrita literária barrosiana que buscou legitimar sua visão de mundo a partir da costura entre política e literatura. Essa costura entre os dois discursos buscou legitimidade no campo da história o qual Barroso, que 
o ocupa um lugar social específico, o de sujeito de saber, intelectual ${ }^{2}$, instrumentaliza dotando o passado de determinados sentidos.

São perguntas norteadoras dessa pesquisa: Quais as tensões e dinâmicas que sua visão de mundo embutida em seu referido projeto encontrou na câmara dos deputados? Como Barroso mobiliza a literatura em função de demandas do seu tempo presente? Qual o seu sentido de tempo e qual o lugar da história em seu discurso?

Nessa empreitada que permeia a relação entre o político, o intelectual e a história nossa principal referência teórica é o pensamento de Michel de Certeau ${ }^{3}$, por meio do qual visamos empreender uma análise do discurso barrosiano, entendo-o como um discurso que está ligado a um “chão social” específico que por sua vez é feito também de tempo, discurso que está comprometido com as tensões e dinâmicas do presente. Outro aporte teórico pelo qual conduzimos nosso pensamento é o expresso por Walter Benjamim em As Teses Sobre o Conceito de História ${ }^{4}$, por meio do qual buscaremos compreender o projeto de lei barrosiano e os elementos por ele mobilizados como registros da barbárie, apoiados numa concepção de história feita sempre pelos opressores, vazia e homogênea, pois imutável e fruto de uma linearidade já dada. Contrário a essa concepção, Walter Benjamin nos abre a possibilidade de pensar o tempo enquanto aberto a novas possibilidades, heterogêneo, inchado, vivo, repleto de agora. Logo, o fazer história é uma prática do e no presente ${ }^{5}$.

Utilizaremos como fontes os anais da câmara dos deputados ${ }^{6}$ e um capítulo específico do livro A Ronda dos Séculos ${ }^{7}$, intitulado Os Dragões do Rei.

Ao percorrermos esse caminho estamos também preocupados com nosso tempo presente, pois entendemos que de formas diferentes o pensamento barrosiano, que sintonizava o campo político e intelectual tendo como elo legitimador o uso da história, é posto para funcionar ainda hoje por uma elite sedenta pela ampliação de seus privilégios de classe e saudosa de um passado em muito idealizado em que cada classe social saberia seu lugar na sociedade e assim vivia harmoniosamente, entendendo qualquer forma de luta, que por um segundo sequer coloque em cheque essa percepção da história, como uma força disruptiva que deve ser controlada, subjugada ou mesmo excluída.

\section{Disputas do campo político e a costura da História.}

"Não darei opinião minha, darei opiniões que estão consignadas na história" ${ }^{8}$. Assim Gustavo Barroso começa a defesa do seu projeto intitulado Os Dragões da Independência. Esse projeto visava exaltar as tradições militares do Brasil a partir da criação da guarda do 
presidente da república, Os Dragões da Independência, com uniforme inspirado na antiga guarda de honra do imperador Dom Pedro I.

Em reunião do dia 27/07/1917 no plenário da câmara o deputado pelo Rio de Janeiro Mauricio de Lacerda ${ }^{9}$ ataca frontalmente o projeto de lei de Gustavo Barroso, alegando a inutilidade do referido projeto. Em seu discurso Mauricio de Lacerda aponta entre outras questões o gasto desnecessário de um novo uniforme. Seu argumento segue em tom jocoso, chegando a sugerir que se o projeto barrosiano fosse aprovado apenas pelo apelo às tradições ele sugeriria um aditivo restaurando uma tradição mais antiga "Imaginem, como bem pareceria um regimento de amazonas garbosamente montadas" $" 10$.

A discussão segue e Lacerda afirma que Barroso por nutrir sentimentos "paternais” em relação ao referido projeto é incapaz de perceber seus defeitos. Barroso prontamente usa do mesmo argumento para afirmar que Lacerda também não enxerga os defeitos do seu projeto sobre o voto feminino ${ }^{11}$. Mais adiante Lacerda diz que se o projeto barrosiano for aprovado ele proporá a criação de um batalhão de amazonas, afinal

\section{é mais histórico e, sobretudo, muito mais elegante. Tendo em vista ainda que na Russia um batalhão era comandado por uma mulher. Por que não hão de ter as brasileiras seu regimento? [...] Imagine V. Ex. um regimento de Dragões, dando ultima carga atrás das amazonas ${ }^{12}$.}

Para Lacerda o projeto de Barroso era inócuo e sobretudo inoportuno frente ao contexto de $1917^{13}$, coisa mesmo de, nas palavras de Lacerda, "costureiro", "modista", "alfaiate" preocupado em fantasiar o exército ${ }^{14}$.

Voltemos à expressão barrosiana com a qual abrimos nosso texto: "Não darei opinião minha, darei opiniões que estão consignadas na história”. Sim, é na história que Barroso vai buscar embasar seu projeto apontando a existência e a importância de regimentos especiais em momentos importantes da história da humanidade, diga-se ocidental, nesse sentido ele vai elencar exemplos como a "Legião Cotovia" de Cezar e os "Hussares da Morte" de Napoleão. O debate entre os dois deputados cai então no campo da história, especificamente na história do regimento militar conhecido como "Janizaros". Barroso acusa Lacerda de usar a "história em falso", Lacerda afirma "conheço a historia" e Barroso retruca "Não conhece" ${ }^{\text {"15 }}$. Gustavo Barroso, que se entendia como senhor do conhecimento, se agarra ao passado "tal como ocorrido" para justificar o presente. Sua percepção de história é assim despolitizada, asséptica. Por meio do mito da objetividade imparcial, seu discurso historiográfico tenta camuflar sua subjetividade, seu lugar social, as relações socioeconômicas que fabricam os sentidos do passado. 
Nesse sentido, acreditamos que nesse quiproquó estava em jogo muito mais do que aparenta. Eram visões de mundo conflitantes que seguindo as regras do campo ${ }^{16}$ político disputavam, por meio da história, da fabricação da história, o presente.

Maurício de Lacerda desenvolvia sua atuação política em estreito contato com organizações operárias comunistas e anarquistas do Rio de Janeiro. Nesse sentido, se empenhou na Câmara em discussões da questão social trabalhista, encaminhando vários projetos no ano de 1917, que visavam a regulamentação de diversos aspectos das condições de trabalho do operariado, além do voto feminino ${ }^{17}$.

Ressaltemos que a classe operária, instituída em diferentes tipos de organizações inspiradas nos ideais anarquistas e comunistas, passava a despontar como novo protagonista na vida pública do Brasil, reagindo contra as péssimas condições de trabalho e lutando por direitos laborais, como férias, salários dignos, jornada de trabalho diária de oito horas e proibição do trabalho infantil. Lutas essas que foram duramente reprimidas, inclusive alguns dias após a discussão entre Barroso e Lacerda ocorreria a primeira greve geral do Brasil promovida por organizações operárias de cunho anarquista e comunista, se destacando como uma das mais abrangentes e longas da história do Brasil ${ }^{18}$.

Lacerda representava as novas forças em ação que sacudia os antigos territórios de poder. Já Gustavo Barroso representava as antigas forças de uma elite decadente rural do norte do país que via seus domínios políticos e econômicos ameaçados por elementos externos, como: a industrialização, a urbanização, o fim do antigo sistema servil, a imigração em massa e os ideais libertários que começavam a desembarcar no Brasil.

Para Barroso era preciso intervir nessa mudança acelerada do tempo e do espaço, era preciso construir territórios fixos, era preciso excluir indesejáveis a partir da elaboração de fórmulas políticas e de saberes que organizassem esse momento entendido como caótico. Nesse sentido é que entendemos o conjunto da atuação política barrosiana. Por exemplo, um outro projeto de lei de sua autoria apelidado de "Os Indesejáveis" que contou com ampla repercussão e apoio de diversos jornais nacionais, visava barrar a entrada no país de mutilados da guerra, criminosos e de todos os indivíduos considerados indesejados, regulamentando a imigração. Segundo Barroso:

\footnotetext{
"Nada ha de mais importante e decisivo para o futuro do Brasil, já tão mal servido ethnicamente e que só com a acção do tempo se irá libertando dos elementos pessimos que o atopem, do que a formação de uma raça physica e moralmente sadia [...] expurgada de sangue máo e de tendencias perniciosas" ${ }^{\prime 19}$.
} 
O Jornal, A Rua, dois anos depois, cobrava "Que os poderes publicos apressem a votação, a sancção e a execução do projecto Gustavo Barroso" e continua "o Brasil precisa defender-se da invasão de extropiados depois da guerra [...] anarchistas e outros que tanto trabalho dão a policia" 20 . Esse outro projeto também suscitou debates fortíssimos na Câmara dos Deputados, nas páginas de jornais, inclusive ganhando espaço na literatura barrosiana ${ }^{21}$.

Para Barroso o momento era entendido mesmo como vertiginoso e para tentar de alguma forma conter, ou ao menos controlar, as mudanças caóticas que atingiam todos os aspectos da sociedade ${ }^{22}$, era preciso intervir com urgência e em todas frentes de batalhas possíveis. Se a modernidade em nome do futuro teria tripartido o tempo em passado, presente e futuro, Gustavo Barroso por meio de sua pratica discursiva buscou costurar a temporalidade, religando o passado ao presente e assim ter garantia de domínio do futuro.

A fórmula encontrada por Barroso foi a construção de uma ideia de nação/identidade que seria buscada nos indícios do passado, no caso específico no regimento dos Dragões da Independência, tratados como vestígios de um tempo que estava se perdendo e que era preciso de alguma forma recuperar. $\mathrm{O}$ dispositivo da nacionalidade funcionaria em sua prática discursiva como homogeneizador das diversas relações sociais e centralizador no âmbito da soberania e da dominação ${ }^{23}$. Essa nação seria encontrada no passado, na busca por símbolos que preencham esse sentimento de vazio causado pela sensação de ruína dos antigos espaços de poder, que o torne dizível, visível, crível, simbolização e materialização ancorada na tradição do Brasil Império, entendido por Barroso como momento áureo da nossa história e como continuador de uma tradição maior, europeia.

É nesse sentido que entendemos o projeto de lei número 71 de 1917, apelidado de "Os Dragões da Independência”, que visava resgatar valores e tradições, e o rumo do debate, a história, escolhido por Barroso na Câmara dos Deputados quando se confrontaram diferentes perspectivas de mundo. Essa tarefa assumida por Gustavo Barroso visa dotar o passado com determinados sentidos, trasladar o pretérito para o presente e assim projetar um horizonte de expectativas. Dessa forma, ao participar da construção do dispositivo nacional, Barroso se faz antimoderno na linha da modernidade, afinal a nação e o discurso nacionalista que a constrói é fruto da modernidade ${ }^{24}$.

Outro aspecto que liga Barroso à modernidade, mesmo que reativo à ela, é o uso do romance com o intuito de articular imagens do passado através de uma narrativa temporal calcada no discurso histórico ${ }^{25}$. Essa costura entre história e literatura, serviço mesmo de 
alfaiate, de costureiro de fios narrativos, operacionalizada pelo discurso barrosiano será objeto de nossa próxima reflexão.

\section{Usos do passado, costuras narrativas entre Literatura e História no discurso barrosiano}

Gustavo Barroso vivenciou e registrou como poucos o período de intensas transformações da nossa história conhecida como Primeira República, tendo sua literatura um papel estratégico para a compreensão das tensões e dinâmicas do seu tempo marcado pelo desenrolar da nova ordem, a ânsia do progresso, e as várias reações à modernidade. Destarte, pretendemos adentrar na análise de um capítulo específico intitulado "Os Dragões do Rei” de seu livro a Ronda dos Séculos ${ }^{26}$, interessando perceber como Barroso utiliza a história por meio da literatura para legitimar seu projeto político de reabilitação do passado.

Alertamos ao leitor que não estamos interessados, nessa pesquisa, se os acontecimentos e personagens narrados por Gustavo Barroso têm pouca ou nenhuma existência concreta, nos interessa mais o entendimento que eles não são registro de um acontecido, mesmo que erigido com materiais da esfera histórica, mas sim registro do mundo que Barroso experenciava e recriava à sua imagem e semelhança, falando de expectativas, medos e anseios que dizem respeito à época de sua escritura e que visa atrair a alma do leitor, tocar seu íntimo, produzir reações, atingir e moldar percepções de mundo ${ }^{27}$, fazendo da literatura também uma arena de luta e interesses.

Ressaltemos também que o Brasil no prelúdio republicano vivenciava uma expansão do seu mercado editorial com suas novas técnicas no processo de impressão aumentando o corpo funcional dos jornais, o qual Barroso participava ativamente, e de seus exemplares, publicando inclusive capítulos de seus livros. Com a expansão do mercado editorial de jornais e livros aumentou também o número de leitores, os quais Barroso buscou atingir por meio de sua atividade literária que caminha pari passu com sua ação enquanto deputado.

Em Os Dragões do Rei, Barroso vai nos falar sobre um valoroso e admirado regimento do exército do rei Luís XIV, os regimentos de dragões "envergando casacas verdes e tendo pelles em volta dos capacetes. O rei amava sua valentia nobre" 28 . Porém o rei e seus generais não admitiam o "supremo luxo que não permitto a oficiaes e soldados nas minhas campanhas" ${ }^{29}$ com o qual o regimento dos dragões se apresentou para aquela campanha. Depois das duras reprimendas reais o destacamento dos Dragões liderado pelo conde Bertigny caiu em desgraça "apezar dos prodigios de bravura [...] as ordens dos genaraes não os mencionavam. Eram como se não existissem. ${ }^{\text {30 }}$. Após repetidos atos de bravura do regimento dos dragões e de ter perdido quase todo seu destacamento Luís XIV finalmente reconhece e 
premia os poucos sobreviventes do destacamento dos dragões que mesmo mutilados e esfarrapados gritam "Viva o rei!" 31 , num sinal de total entrega e compromisso com a causa real.

A representação do passado que Barroso nos traz nesse conto não fala só de um acontecido, mas é sobretudo um registro de como ele pensava o mundo à sua volta nos dizendo mais sobre seu momento de feitura que sobre o momento narrado. Aqui temos a literatura barrosiana sendo costurada com a história, tecendo uma arena de luta e interesses que giram em torno do seu projeto sobre os Dragões da Independência.

Nesse conto Barroso retoma o debate travado com Mauricio de Lacerda e, assim como na Câmara dos Deputados, vai buscar no pretérito europeu elementos que singularizem sua ideia de nação. O aditivo é que seu discurso agora rompe os muros da Câmara dos Deputados e se materializa em forma de literatura. Ao mundo instável do progresso, Barroso, artesão do tempo, busca costurar um passado militar para o Brasil, remendado com um passado europeu, que supere o rasgo temporal entre passado e presente que a história moderna causou ${ }^{32}$.

Ao narrar a história do regimento dos dragões do rei Luís XIV, recheada de atos de bravura, de entrega a uma causa, de fidelidade ao soberano francês, Barroso buscava aproximar o Brasil da França, conferindo uma tradição maior ao regimento dos Dragões da Independência que Barroso buscava trazer de volta por meio de seu projeto de lei. Para Barroso essa tradição militar e heroica do Brasil Império, que tinha raízes na Europa Ocidental, deveria servir de alicerce para a nação, esta que se perdia frente ao avanço da modernidade e da modernização. O Brasil Império é o molde nacional, momento este que Barroso entende como esplendoroso. Os sujeitos privilegiados de seu discurso são personas ilustres, reis, generais, o cenário é de vitórias militares. Tudo em contraposição à República, entendida como caótica, fragmentada, desordenada, perdida, com a entrada de novos atores sociais em cena.

Cabe ressaltar que Barroso, assim como respondeu à Lacerda, está consignado na história, no uso da história, se legitimando como detentor do saber, intelectual, que saberia conduzir o país, fazendo da nação um só corpo e uma só alma, nação uniformizada, em que os rostos que não se encaixassem em seu projeto deveriam ser perseguidos, marginalizados, excluídos, pois “indesejáveis”.

Os (in)desejáveis de Barroso, tinham, cara, cor e ideologia, seu discurso homogeneizador tinha um lugar e como todo lugar ele tem um tempo. O lugar do discurso barrosiano tem o tempo dentro de si. 


\section{O Lugar do Tempo em Gustavo Barroso: o antimoderno na linha da modernidade}

Assim como em seu debate com Mauricio de Lacerda, Barroso por meio da literatura buscou legitimidade para seu projeto de lei no campo da história. A narrativa barrosiana é uma representação do passado que por meio da literatura visa usar uma dada concepção de tempo para instituir uma realidade. Qual seria essa concepção de tempo? Como se dá a fabricação desse tempo? Com que fins? Comecemos a responder pelo final de nossas problematizações.

Entendemos que Gustavo Barroso faz caminhar sua ação política pari passu com sua atividade intelectual e que por meio da análise dessas atividades podemos compreender mais sobre as transformações que a sociedade brasileira passava nas primeiras décadas do século XX. No prelúdio republicano a ânsia do progresso dava o tom das transformações, saíamos de uma sociedade baseada nos valores tradicionais, de uma sociedade patriarcal rural para uma sociedade cada vez mais urbana, cosmopolita em que as transformações e descobertas técnico-científicas se davam num ritmo considerado por muitos como violento. Novos espaços, novas ideias e novos atores entravam em cena desestabilizando com seus novos padrões de sociabilidade e sensibilidade antigas relações sociais e de poder.

Para Barroso, criado sob a égide dos antigos valores, a sensação de perder o controle sob essas mudanças era algo assustador. Era preciso de alguma forma frear ou ao menos tomar as rédeas dessas transformações. É nesse sentido que podemos destacar sua ação política em total sintonia com sua atividade literária. O projeto de lei dos Dragões da Independência funciona exatamente no sentido de construir o Brasil por meio de seu passado, dando-lhe existência presente e projetando-o para o futuro. Portanto, para se sentir seguro frente às transformações que atingiam todos os níveis da experiência social, alterando hierarquias sociais, convicções, valores, percepções de tempo e espaço, formas de ser e estar no mundo, Barroso fabrica sua concepção de passado.

Se para a modernidade o que há de mais "sagrado" é a aceleração, para Barroso o Brasil almejado tinha suas raízes no passado, num tempo entendido quase como imóvel, tempos de grandes reis, imperadores e generais, de grandes proezas e sacrifícios militares, de grandes vitórias. Do imperador romano ao rei francês, desembocando no resgate de uma tradição do tempo do Brasil Império, sua história está assim comprometida com o ponto de vistas dos vencedores, uma percepção temporal acumuladora de datas, de grandes acontecimentos e personagens que acredita ser a representação de um passado "tal como 
acontecido". Destarte, Barroso criticava a modernidade ao mesmo tempo em que os fios narrativos de seu tecido histórico baseavam-se no modo de pensar e escrever a história nos moldes do positivismo do século XIX e da modernidade.

A fabricação da história em Gustavo Barroso, como pudemos acompanhar em seu discurso na Câmara dos Deputados e no capítulo de seu livro aqui analisado, camufla por trás da figuração do passado a práxis que o organiza. Ou seja, Barroso entende o passado como uma vasta acumulação de acontecimentos, sempre do ponto de vista oficial, dos vencedores, tratando o passado como algo natural, sua história embora reativa à modernidade se faz no campo do saber moderno que propõem uma história neutra, desinteressada, apoiada em instituições científicas e oficiais, do qual ele seria porta-voz. Colocando a história sob controle, sua narrativa que fabrica o real é imperativa, camuflada sob uma suposta neutralidade, nesses termos Barroso não dá sua opinião à Lacerda, nem em seu livro, o seu discurso "está consignado na história”, uma história que se pretende objetiva, despolitizada, limpa. Dessa forma, Barroso faz conhecer o passado à maneira de quem dá uma ordem.

A trama temporal do discurso barrosiano que se pretende real, pois científica, se realiza ocultando seu lugar de porta-voz de uma elite decadente desejosa de ao menos manter seus privilégios. O engenho institucional que autoriza sua concepção de história é o discurso científico moderno. Seu discurso não se entende como ficção, fruto da subjetividade, seu discurso se pretende real porque se diz baseado na história. Mas, sua narrativa que se pretende real é produto de um meio, de um lugar, de condicionantes socioeconômicos, forças do presente que organizam representações do passado, afim de controlar o próprio presente e projetar o futuro desejado.

O lugar de fala de Gustavo Barroso, camuflado por sua operação historiográfica, é o de uma elite reativa à República e ansiosa de domar as forças do progresso, pesarosa pela sensação de perda de espaços políticos e econômicos, assustada com a velocidade das mudanças e com a revolta daqueles que lutavam contra a exclusão social. Para dar um sentido de organização ao caos em que se via mergulhado é que Barroso busca, pela ação política e literária, legitimada pelo uso da história, reorientar seu tempo reabilitando os Dragões da Independência, uniforme não apenas para militares, mas que devia vestir a nação. Nação uniformizada ao molde barrosiano, reabilitação de um passado entendido como glorioso que se perdia frente aos avanços da modernidade, passado que devia seguir sua marcha linear sem transformações abruptas. 


\section{Considerações Finais}

O discurso barrosiano tem um lugar de fala que, legitimado pelo saber científico, busca no passado um projeto de nação. Ao procurar controlar o sentimento de perda de seus territórios, de poder, de domínio, Barroso membro de uma elite tradicional rural decadente inicia assim um processo reativo à modernidade que mais fala de um sentimento de fragilidade que da potência do seu articulador.

O debate em que Barroso se insere deve ser pensado como um campo de batalhas, travadas não só entre armas e exércitos, mas pelo poder da narrativa, da enunciação, revelando a busca dele em ordenar o espaço da nação, não só no plano das ideias, mas também no plano político, onde o se pensar a nação seria definir também seu próprio papel no cenário da política nacional.

É a partir desse não-dito, seu lugar social, que Barroso vai compor sua trama discursiva blindado, legitimado, pelo saber histórico científico que se considera neutro. Em sua concepção de história lhe interessam apenas os grandes feitos, dos grandes reis e militares, a defesa dessa tradição e tudo que ela representa é seu esteio, é nela que ele encontra os fundamentos da nação. História que seguia numa linearidade preenchida com datas e grandes nomes reais. Nação, que ele entendia, ameaçada por crenças e valores subversivos às ordens tradicionais. Linearidade que se rompia com o advento da modernidade e da modernização que trazia em seu bojo forças disruptivas que contestavam e abalavam a posição dominadora dos patrões e dos tradicionais senhores em muito formados pela concepção do antigo regime servil ${ }^{33}$, forças que deveriam ser domadas e em última instância aniquiladas, pois indesejáveis, ao rosto nacional barrosiano.

À crise causada pela lacuna entre passado e presente, criada pela modernidade, Barroso propôs, visando o futuro que parecia escapar às suas mãos, uma "ponte para o passado". Projetado no seu presente, essa ponte para o passado almejou pelo resgate da tradição militar dos Dragões da Independência um retorno para um mundo que ele entendia como glorioso e harmonioso, assentado na vida patriarcal, na inviolabilidade do senhor da casa-grande, mundo que se perdia frente ao avanço da modernidade que em nome do progresso se tornava não menos excludente que a antiga ordem.

Seja numa perspectiva que tenciona religar o presente a um passado em muito imaginado a partir de elementos buscados sob a égide da tradição e do conservadorismo, seja a ideia historicista de progresso linear, o que está em pauta é uma percepção de tempo vazio e 
homogêneo, acumulador de datas e grandes "heróis nacionais", universal e imutável, encadeamento histórico determinado por leis que representam na verdade uma narrativa naturalizada contada a partir do ponto de vista dos vencedores ${ }^{34}$. Nesse sentido, entendemos que por meio do projeto de lei "Os Dragões da Independência” e do conto "Os Dragões do Rei”, Gustavo Barroso faz uma leitura do passado entendido tal como ocorrido, com o objetivo de ordenar o mundo à sua volta, buscando se (re)ligar com uma representação de um passado tido como harmonioso construído pela ação de grandes heróis nacionais que tinham suas raízes em tradições europeias, apresentando uma imagem eterna do passado.

Perspectiva histórica contada a partir do ponto de vista dos vencedores, projeto de lei que entendemos ser um documento da barbárie que nos conta mais sobre a dominação do homem pelo homem e do esforço de se manter seus privilégios vistos como ameaçados. Acreditamos assim, que problematizar essa questão é de certa forma contribuir para a explosão do continuum da história, ver a história não como de fato ocorreu, mas a partir do momento presente de sua tessitura que está intrinsicamente ligada a um chão social, é um primeiro movimento na direção de "pentear a história a contrapelo", abrindo assim a história para novas interpretações, inclusive levando em conta a perspectivas dos explorados e oprimidos.

No Brasil do início do século XXI, os herdeiros da casa-grande continuam construindo "pontes" a partir de suas próprias experiências espaço-temporais. Incorporando novas reflexões e perspectivas são erigidas hoje "pontes para o futuro" que passam pelas curvas do passado. Passado uniformizado, passado que alguns buscam nas "glórias" das tradições militares do Brasil Império e/ou do regime civil-militar. Uniformização da nação que se costura ao pensamento barrosiano, ligado a concepção de história vista de cima, vista por aqueles que, de diferentes formas, não cessaram de vencer.

\section{NOTAS}

\footnotetext{
${ }^{1}$ MOREIRA, Afonsina Maria Augusto. No norte da saudade: Esquecimento e Memória em Gustavo Barroso. 301 f. Tese (Doutorado) -, História Social do Departamento de História da Pontifícia Universidade Católica de São Paulo, São Paulo, 2006. p.9-10.

${ }^{2}$ Partimos da definição de intelectual proposta por Sirinelli, que entende o intelectual como um conjunto de sujeitos específicos, considerados como criadores e mediadores culturais, bem como ator engajado e militante, categorias essas que se complementam, ver: SIRINELLI, Jean- François. Os intelectuais. In: REMOND, René (org.). Por uma história política. $2^{\circ}$ ed. Rio de Janeiro: Editora Fundação Getúlio Vargas, 2003. p.242-243.

${ }^{3}$ CERTEAU, Michel de. História e psicanálise: ente ciência e ficção. Belo Horizonte: Autêntica, 2011.

${ }^{4}$ BENJAMIN, Walter. As Teses sobre o Conceito de História. In: Obras Escolhidas, Vol. 1, p. 222-232. São Paulo, Brasiliense, 1985.

${ }^{5}$ Ibid., p. 224.
} 
${ }^{6}$ BRASIL. Congresso Nacional. Anais do Congresso Nacional. Rio de Janeiro: Imprensa Nacional, 1917 (n. 48). Disponível em: <http://www2.camara.leg.br/documentos-e-pesquisa/diariosdacamara> Acesso em 10 de agosto de 2016.

${ }^{7}$ BARROSO, Gustavo. A Ronda dos Séculos. Rio de Janeiro: Livraria Editora de Leite Ribeiro \&Maurillo, 1920.

${ }^{8}$ BRASIL, op. cit., 1917, p.693.

${ }^{9}$ Maurício Paiva de Lacerda nasceu em Vassouras (RJ), em 1888. Advogado, formou-se pela Faculdade de Direito do Rio de Janeiro, em 1909. Exerceu o cargo de oficial de gabinete do presidente Hermes da Fonseca entre 1910 e 1912. Nesse ano, elegeu-se deputado federal pelo Estado do Rio, reelegendo-se em 1915 e 1918. Nesse período, acumulou, ainda, o cargo de prefeito de Vassouras 1915-1920. Disponível em: <http://cpdoc.fgv.br/producao/dossies/AEraVargas1/biografias/mauricio_lacerda> Acesso em 10 de Julho de 2017.

${ }^{10}$ BRASIL, op. cit., 1917, p.692.

${ }^{11}$ Ibid., p.692.

${ }^{12}$ Ibid., p.692-693.

${ }^{13}$ Nesse sentido um fator que parece preocupar Lacerda é o desenrolar da Guerra e a iminente participação do Brasil nela. A esse respeito Mendonça nos traça um panorama decadente do estado da Forças Armadas brasileiras nesse período: "As Forças Armadas brasileiras, em termos de poder de combate, eram uma nulidade: arsenais desaparelhados, pessoal improdutivo, quartéis depauperados, navios inoperantes, falta de equipamentos, ausência de instrução. As seguidas gestões de reduzidos orçamentos e de baixa eficiência administrativa converteram o Exército e a Marinha em instituições atrasadas e decadentes". Sobre a situação das Forças Armadas brasileiras e a entrada do Brasil na Primeira Guerra, ver: MENDONÇA, Valterian Braga. A experiência estratégica brasileira na Primeira Guerra Mundial, 1914-1918. Dissertação (Mestrado em Ciência Política) - Universidade Federal Fluminense, Rio de Janeiro, 2008. p.49.

${ }_{15}^{14}$ BRASIL, op. cit., 1917, p.693.

${ }^{15}$ Ibid., p. 693.

${ }^{16}$ Seguimos em nosso texto com a noção de campo proposta por Pierre Bourdieu, que nos lança subsídios para que possamos compreender os campos como espaços sociais com suas próprias regras, princípios e hierarquia, com delimitações definidas a partir, não só dos acordos e consensos, mas também a partir dos conflitos, tensões e dinâmicas. Ver: BORDIEU, P. Razões Práticas: sobre a teoria da ação. 11. ed. Campinas/SP: Papirus, 2011.

${ }^{17}$ Disponível em: <http://cpdoc.fgv.br/producao/dossies/AEraVargas1/biografias/mauricio_lacerda> Acesso em 10 de Julho de 2017.

${ }^{18}$ Sobre as origens do movimento operário no Brasil, ver: CARONE, E. Movimento operário no Brasil: $1877-$ 1944. São Paulo: DIFEL, 1979.

${ }^{19}$ In: Jornal, A Rua, 23, de setembro, 1916. Disponível em: http://memoria.bn.br/hdb/periodico.aspx. Acesso em: 15 de agosto 2016.

${ }^{20}$ In: Jornal, A Rua, 25, de novembro, 1918. Disponível em: http://memoria.bn.br/hdb/periodico.aspx. Acesso em: 15 de agosto 2016.

${ }^{21}$ Não é nosso objetivo agora adentrarmos numa análise mais aprofundada sobre o projeto de lei "Os Indesejáveis" de Gustavo Barroso e seus desdobramentos pela limitação de espaço do artigo. Passamos por ele apenas como demonstrativo das relações de força, tensões e dinâmicas que extrapolavam os limites da Câmara dos Deputados, e que visavam construir determinadas ideias de nação e identidade então em voga no Brasil durante as primeiras décadas do século XX.

${ }^{22}$ Sobre o intenso fluxo de mudanças que atingiam todos os níveis da experiência social no Brasil e no mundo entre fins do século XIX e meados do século XX, ver: SEVCENKO, Nicolau. O prelúdio republicano, astúcias da ordem e ilusões do progresso. In: NOVAIS, F. (Org.). História da vida privada no Brasil-República: da belle époque à era do rádio, v. 3, 7. reimp., São Paulo: Cia das Letras, 1998, p. 7- 48.

${ }^{23}$ Sobre os usos do dispositivo da nacionalidade por uma elite intelectual brasileira desejosa de guiar os rumos do Brasil no começo do século XX, ver: ALBUQUERQUE JR. Durval Muniz de. A moldura das nacionalidades: a construção imaginária da nação brasileira no século XX, p.2. Disponível em: <http://www.cchla.ufrn.br/ppgh/docentes/durval/artigos/segunda_remessa/Brasil500.pdf> Acesso em 20 mar. 2011.

${ }^{24}$ Sobre o nacionalismo moderno e a invenção da nação, ver: HOBSBAWN, Eric J. Nação e Nacionalismo desde 1780. Rio de Janeiro, Paz e Terra, 1990.

${ }^{25}$ Sobre como os romancistas assumiram a tarefa de compreender o passado, ver: RAMOS, F. R.L. José de Alencar e a operação historiográfica: fronteiras e disputas entre história e literatura. História da Historiografia, v. 18, p. 160-177, 2015. 


\footnotetext{
${ }^{26}$ Embora publicado apenas em 1920, o livro é iniciado durante o seu mandato como Deputado Federal, como dito por ele próprio no referido livro. BARROSO, Gustavo. A Ronda dos Séculos. Rio de Janeiro: Livraria Editora de Leite Ribeiro \& Maurillo, 1920.

${ }^{27}$ Sobre a relação entre arte e história, ver: PESAVENTO, S. J. Este mundo verdadeiro das coisas de mentira: entre a arte e a história. Revista Estudos Históricos, Rio de Janeiro, no 30. 2002. p. 56-75.

${ }^{28}$ BARROSO, op. cit., 1920. p.272-273.

${ }^{29}$ Ibid., p. 274.

${ }^{30}$ Ibid., p. 275.

${ }^{31}$ Ibid., p. 279.

${ }^{32}$ Para Certeau a história moderna ocidental se caracteriza pela separação entre o passado e o presente. Ver CERTEAU, Michel de. A escrita da história. Rio de Janeiro: Forense Universitária, 1982, p.14.

${ }^{33}$ Sobre o papel das elites na formação do Brasil, ver: PRADO JUNIOR, Caio. História Econômica do Brasil. São Paulo: Brasiliense, 1994. p. 212-215.

${ }^{34}$ À luz do entendimento de Walter Benjamin pensamos que o passado está longe de estar morto, de ter um único sentido. O passado é parte do presente, é no presente que versões do passado são fabricadas, a partir dos signos deixados pelo passado. Nesse sentido, entendemos o fazer historiográfico como um campo aberto e múltiplo de sentidos e significados conectado com as demandas do presente. Ver: BENJAMIN, op.cit., 1985.
}

\section{Fontes:}

Anais da Câmara dos Deputados 1915-1918. Disponível em: http://www2.camara.leg.br/documentos-e-pesquisa/diariosdacamara. Acesso em 10 de agosto 2016.

BARROSO, Gustavo. A Ronda dos Séculos. Rio de Janeiro: Livraria Editora de Leite Ribeiro \&Maurillo, 1920.

Jornal, A Rua, 23, de setembro, 1916. Disponível em: <http://memoria.bn.br/hdb/periodico.aspx>. Acesso em: 15 de agosto 2016.

Jornal, A Rua, 25, de novembro, 1918. Disponível em: <http://memoria.bn.br/hdb/periodico.aspx>. Acesso em: 15 de agosto 2016.

\section{Referências Bibliográficas}

ALBUQUERQUE JR. Durval Muniz de. A moldura das nacionalidades: a construção imaginária da nação brasileira no século XX. Disponível em:〈http://www.cchla.ufrn.br/ppgh/docentes/durval/artigos/segunda_remessa/Brasil500.pdf > Acesso em 20 de março de 2011.

BENJAMIN, Walter. As Teses sobre o Conceito de História. In: Obras Escolhidas, Vol. 1, p. 222-232. São Paulo, Brasiliense, 1985.

BORDIEU, Pierre. Razões Práticas: sobre a teoria da ação. Campinas/SP: papiros, 2011. 11 ed.

CARONE, E. Movimento operário no Brasil: 1877-1944. São Paulo: DIFEL, 1979.

CERTEAU, Michel de. História e psicanálise: ente ciência e ficção. Belo Horizonte: Autêntica, 2011.

. A escrita da história. Rio de Janeiro: Forense Universitária, 1982.

FERREIRA, J \& DELGADO, L. de A. N. (Org.). O Brasil republicano - o tempo do nacional-estatismo: do início da década de 1930 ao apogeu do Estado Novo. Rio de Janeiro: Civilização Brasileira, 2003.

HOBSBAWN, Eric J. Nação e Nacionalismo desde 1780. Rio de Janeiro, Paz e Terra, 1990. 
MENDONÇA, Valterian Braga. A experiência estratégica brasileira na Primeira Guerra Mundial, 1914-1918. Dissertação (Mestrado em Ciência Política) - Universidade Federal Fluminense, Rio de Janeiro, 2008.

MOREIRA, Afonsina Maria Augusto. No norte da saudade: Esquecimento e Memória em Gustavo Barroso. 301 f. Tese (Doutorado) -, História Social do Departamento de História da Pontifícia Universidade Católica de São Paulo, São Paulo, 2006.

PRADO JUNIOR, Caio. História Econômica do Brasil. São Paulo: Brasiliense, 1994.

PESAVENTO, S. J. Este mundo verdadeiro das coisas de mentira: entre a arte e a história. Revista Estudos Históricos, Rio de Janeiro, n³0. 2002. p. 56-75.

RAMOS, F. R.L. José de Alencar e a operação historiográfica: fronteiras e disputas entre história e literatura. História da Historiografia, v. 18, p. 160-177, 2015.

SEVCENKO, Nicolau. O prelúdio republicano, astúcias da ordem e ilusões do progresso. In: NOVAIS, F. (Org.).História da vida privada no Brasil-República: da belle époque à era do rádio, v. 3, 7.reimp., São Paulo: Cia das Letras, 1998, p. 7- 48.

SIRINELLI, Jean- François. Os intelectuais. In: REMOND, René (org.). Por uma história política. $2^{\circ}$ ed.Rio de Janeiro: Editora Fundação Getúlio Vargas, 2003. 